\title{
Psychological distress of dementia patient caregivers residing in Russia and Kazakhstan
}

Venera Telzhan

Candidate for the Master in Neuroscience, (Neuropsychology)

SAERA International Institute, Kazakhstan, Nursultan city, 2020.

\author{
* Correspondence author \\ Venera Telzhan \\ Candidate for the Master in Neuroscience, \\ (Neuropsychology) \\ SAERA International Institute, Kazakhstan, Nursultan city, \\ 2020.
}

Submitted : 11 Oct 2021 ; Published : 3 Nov 2021

\begin{abstract}
The present work addresses the question of psychological distress of the caregivers of patients with dementia. The research covers caregivers residing in Russia and Kazakhstan. The thesis starts with concluding the pre-existing knowledge on the research question, from which the author develops the methods for collection of the primary data. Methodology of the research is designed to analyze the data in a qualitative approach. The thesis builds an understanding of the state of psychological distress in which caregivers of Kazakhstan and Russia live in. To do that, the author conducted a survey with range of multiple choice and open questions that examined the stress triggers and proof of the existence of stress in their lives based on answers. A total of 52 active caregivers answered to a survey consisting of 22 questions. The results show that Russian and Kazakhstani caregivers experience moderate to severe levels of psychological distress due to insufficient funding and informational support, among other reasons.
\end{abstract}

Keywords : psychological distress, dementia, caregiver, caregiver burden

Psychological distress of dementia patient caregivers residing in Russia and Kazakhstan

The present thesis focuses on studying the psychological distress among the people who take care of patients with dementia. Dementia is one of the problems that have not been solved by the healthcare organizations, scientists and states. According to a fact sheet provided by the World Health Organization (further WHO), dementia is a chronic syndrome often with rapid deterioration pace that affects the cognitive abilities of a person due to a disease, ageing, strike or other factors (World Health Organization, 2021). Patients suffering from dementia may have a various level of impairment of cognitive function. Areas of cognition such as "memory, thinking, orientation, comprehension, calculation, learning capacity, language, and judgement" can be damaged (World Health Organization, 2021). In addition, patients may experience degradation of emotional state, worsened behaviour, and lack of motivation.

As the number of patients with Alzheimer's disease and other diseases that lead to dementia is steadily rising. In fact, according to the information provided by WHO, there are around fifty million people with dementia worldwide, and this figure rises by $20 \%$ each year (World Health Organization., n.d.). Almost every 20th person aged 60 and more add to the list of the dementia patients. What is even more dispiriting, this number is about to increase by $36 \%$ by 2030 and by $153 \%$ by 2050 . This means that in 10 years, there will be at least 80 million caregivers.

It is clear that caregivers and people living with a patient with dementia in one household suffers from a combination of stressful emotions. In addition to that, taking care of such patient requires high finance and time contribution. Moreover, as dementia patients need continuous support, the social lives of caregivers and family members are restricted as well.

With the rising number of dementia patients, the number of people suffering from stress associated with the following causes will rise as well. Thus, the society will face a problem of maintaining the mental health of the named contingent. In order to prevent worsening of the situation and in order to develop efficient measures for treating stress of dementia caregivers, sufficient research needs to be conducted. Moreover, according to $\mathrm{WHO}$, a greater proportion of such patients live in countries with middle or low household incomes (World Health Organization., n.d.). This means that caregivers are not provided with needed material and psychological support. All of this signifies of the high importance of studying dementia caregiver's psychological stress.

The present dissertation aims to study psychological stress related to giving care to dementia patients and the ways these people cope with this stress. In other words, feelings of 
caregivers, triggers for stressful situations, general awareness of caregiver mental health, availability of organizations for stress-relief, and many other details affecting the extent of psychological stress will be studied. To fulfil the aim of the thesis, the author will conduct a survey of acting dementia caregivers in order to analyse their perception on the research topic. In order to do that, the basis for the research needs to be built. For this purpose, the study will be conducted based on systematically reviewing the existing literature. Studying the literature on the relevant topic will help to build the research on existing up-to-date knowledge. Thus, a thorough analysis of theoretical and practical aspects of the research subject will be conducted. Correspondingly, the following part will present an overview of the literature review.

\section{Literature review}

Numerous scientists have studied dementia disease: emergence, symptoms, preventive measures and treatment. As the number of patients rose, the caregivers became focus of studies as well. It is evident that taking care of a patient with Alzheimer's is challenging and costly. Moreover, these patients need constant care, devotion and considerable physical effort to provide basic hygienic treatment.

For example, the handbook prepared by the Alzheimer's association states that there are ten common problems connected with caregiving to patients with dementia. They are "denial, anger, social withdrawal, anxiety, depression, exhaustion, sleeplessness, irritability, lack of concentration and greater mental and physical health problems" (Alzheimer's Association, n.d.). The list of the symptoms and negative results of taking care of dementia patients will definitely cause worsening of the caregivers' health at some point in future. What is more important, all of the mentioned problems inevitably affect psychological health of a person. Without a proper and timely treatment, any of these will develop into a separate psychological disease and lead to worsening of the family situation. Some of the solutions proposed by the aforementioned association are to take occasional breaks from being a constant caregiver. If the patient is in safe conditions, caregivers ought to give themselves some time in a different environment, which will help them relax. Moreover, it is advisable for such people to engage in communities of similar caregivers. This way, people will be able to share information and practical advice. Moreover, communities help the people to ease their anxiety because of seeing people in a similar situation calms caregivers to some extent. Moreover, the Alzheimer Association advises the caregivers to seek information in order to stay informed regarding the most recent inventions and solutions to typical problems of dementia caregivers (Alzheimer's Disease and Dementia, n.d.).

A prominent work has been prepared by Berg-Weger \& Tebb (2003). They have listed the articles dedicated to the caregiver burden in order to find gaps in the knowledge. This article has a practical importance for the present thesis, as the methodology applied by the Berg-Weger \& Tebb's (2003) serves as a good example of qualitative research in a field of psychology. The conclusions of the research are that at that time, the analysis was conducted having more bias such as gender and ethnic bias. Moreover, authors explain that for better understanding of the scope of the problem, evidence-based practices need to be employed.

There are a number of scholarly papers that study the matter even deeper. For instance, Ferrara et al. (2008) have investigated the relationship between depressions, stress related diseases and caregiving to dementia patients. In order to do that, they conducted a linear regression. The population of the study has been asked to answer a number of questions, based on which a dataset have been created. The respondents were asked their age, gender, gender of the patient with dementia, their education level, occupation, how they were related to the patient and their financial sufficiency. Moreover, the variables for the regression analysis were the examination of mental state and nervous system. Having conducted the research, Ferrara et al. (2008) concluded that the caregiver mental problem exists and needs solving.

De Cola et al. (2017) examine the extent to which caregivers are short of support in the example of Italian families. They have asked a number of questions from dementia patients (when they were able to answer) and their caregivers in order to reveal to what extent each of them thought no support has been received. Moreover, issues such as lack of information for the caregivers and absence of special medical treatment has been discussed as well. As a conclusion of their work, authors declare that in the case of Italian families, caregiving involves a number of factors that worsen the physical, psychological and mental state of the caregivers. The authors explain that each of the caregiver spent long hours during a day supporting the patient. This support includes maintaining their personal hygiene, feeding them, helping them to take drugs and other direct support. In addition to that, caregivers were forced to keep a constant eye on the patient. This made them reorganize their own lives. De Cola et al. (2017, p. 5) conclude by stating that "spaces and roles required assisting the patient expose the entire family to stress and pressures that threaten to destabilize, even dramatically, their "equilibrium."

Podgorski \& King (2009) have examined the dynamics of the changes occurred after the patients were diagnosed with dementia. They have differentiated the changes in family lives based on stages of dementia. They are early-stage, middlestage and late-stage dementia. The early stage is the stage before the disease is diagnosed and the signs of dementia did not prominently show. At this stage, the lifestyles of the entire concerned people are not affected. Podgorski \& King (2009) citing the article of Logsdon, McCurry and Teri (2007) emphasize the importance of acquiring needed knowledge about the disease progression and the timely medical tests. This means that the availability of full and understandable information for the dementia patients and their caregivers may affect their future state of mental and physical health. As the significance of raising awareness is high, the respondents for the present work should be asked if they are given enough informational support. 
With the beginning of the middle stage, as Podgorski \& King (2009) suggest, the dynamics within the family change greatly. The family members will begin to feel the distress. There are two sources for such a distress. On the one hand, they feel the so-called "anticipatory grief" (Podgorski \& King, 2009, p. 25). Anticipatory grief refers to a feeling of sadness related to anticipation of upcoming challenges and future changes in relative's health. Sweeting \& Gilhooly (1990) explains that people feeling anticipatory grief go through the same stages as a real grief. Thus, psychologically it is challenging for the patient and the caregiver. Overcoming this grief during the middle level progression of the disease can be difficult for September 11). The certain group of people will need to seek for specialist help. This includes both patients and caregivers. Thus, that is the stage where psychological distress of the caregivers is expected to start.

Moreover, in the middle stage of the dementia, the relationship between the family members may worsen. This is connected with the fact that dementia patients start needing continuous support and the family members will need to make a tough decision of giving up their jobs, hobbies, and spare time. At this stage, siblings or spouses may become annoyed at each based conclusion stating that "family conflict is most prevalent in cases of mild to moderate dementia, most often between or fail to communicate entirely" (Podgorski \& King, 2009, p. illness of the relative, the caregivers are stressed by worsening of the relationship with the closest relatives. At this point, they may feel emotions such as disappointment, sadness, aggression, frustration and abandonment. Together with a newly emerged responsibility of constant surveillance over dementia patients, these feeling lead to a substantial worsening of the mental health of the caregiver. Most of the times, these problems are accompanied by sleep deprivation and insufficient diet (Gibson et al., 2014; Leggett et al., 2018). In fact, several scholars emphasize the importance of healthy family relationships for future mental health of a main caregiver (Podgorski \& King, 2009; Steadman, Tremont, and Davis, 2007; LoboPrabhu, Molinari \& Lomax, 2006). Depression and anxiety are said to emerge from the initial conflict at the middle-stage dementia. Moreover, authors such as Podgorski \& King (2009) and Steadman, Tremont, and Davis (2007) agree on the opinion that pre-existing understanding between the siblings and spouses helps to establish fare and adequate responsibility sharing. This helps to avoid many direct conditions that lead to a psychological distress. Thus, in order to examine the extent to which the studied group has healthy relations with the family members and how the responsibilities are shared between them, this need to be included in the questionnaire. Steadman, Tremont, and Davis (2007) list possible indices that can be used to measure the caregiver perception of his distress and discontent. They can also be used to anticipate future distress, depression and other mental diseases. These indices are "caregiver perceptions of current problems, satisfaction some people and impossible for another (Relojo-Howell, 2020, other for not sharing the responsibility. There is an evidencesiblings, who may make accusations of neglect or exploitation 25 ). In other words, except being saddened by the fact of the

and amount of social support, available resources, coping skills, and feelings of self-efficacy" (Steadman, Tremont, and Davis, 2007, p. 116).

Steadman, Tremont and Davis (2007) have conducted an important work in appraising the caregiver distress. They have studied 72 patient-caregiver pairs who lived together. The focus area was the relationship satisfaction level before the patient was diagnosed with dementia. In other words, the relationship quality that existed prior to finding out about the disease significantly influenced the consequent caregiver stress amount. This aligns with Podgorski \& King's (2009) view of the family dynamics in middle stage dementia. Nevertheless, Steadman, Tremont and Davis (2007) perform a statistical analysis of the variables such as the premorbid relationship satisfaction, burden survey and other questionnaires and checklists. The results have been regressed, and, the findings are as follows.

Caregivers with retrospective reports of low premorbid relationship satisfaction perceived greater burden than caregivers with retrospective reports of high premorbid relationship satisfaction. We also found that caregivers with less premorbid relationship satisfaction were more likely to negatively react to patients' behavior and have strained communication and problem solving skills (Steadman, Tremont, and Davis, 2007, p. 119).

The aforementioned can serve as a possible predictor of a caregiver burden after the dementia is diagnosed. The authors explain that if the perceptions of the caregivers were modified and relationship problems were worked out, the caregiver burden would decrease and the caregivers would feel themselves less stressed (Steadman, Tremont, and Davis, 2007, Kales, H., Gitlin, L., \& Lyketsos, C., 2014).

The last and the most severe caregiver psychological stress is connected with late-stage dementia. At this stage, the patients' behavior deteriorates significantly and their functionality falls. At this stage, the relatives will need to constantly watch the patient and help with all necessities including personal hygiene. In some case, caregivers will have to carry the patient around. There are several stress triggers for caregivers at this point. The first, a certain category of caregivers will need to quit their jobs and social life. This adds up to other stress stimuli as the person giving up his daily activities, routine and financial independence.

Another problem that the caregivers face at this stage is connected with making a decision to place a patient in a specialized geriatric care centers. However, Podgorski \& King (2009) suggest that caregivers who had problems in relationship with the patient before the illness, and, those who did not receive any support are inclined to feel less stress at the moment of placing a patient in the specialized center. Other categories of caregivers may be exposed to stress for not bearing the challenges. They accept the case of institutionalization of the patients as an example of betrayal. As they felt guilt, they are likely to have psychological problems as well. 
Drebing, McCarty \& Lombardo (2002) investigate the level of stress that employees of geriatric centers were exposed to while working with late-stage dementia. In the case of nonrelative caregiver, not only disease related triggers affect the stress levels of the caregiver, but also the negative attitude and overly high expectations of the relatives.

All of the aforementioned mainly concerned siblings. However, there are cases when a caregiver is a spouse of the dementia patients. Kaizik et al. (2017) compare the caregiver burden of spouses versus other relatives. They found out that spouses felt more stressed and more miserable because their lives were out of control due to a spouse's disease. However, the surprising conclusion made by Kaizik et al. (2017) is that overall level of stress was higher for children of dementia patients compared to spouses.

Having analysed the existing literature, the table has been created. The table summarizes the key features of studies conducted on the subject of psychological stress of dementia carers.

\begin{tabular}{|l|l|l|l|}
\hline $\begin{array}{l}\text { Year of } \\
\text { publication }\end{array}$ & $\begin{array}{l}\text { Author } / \\
\text { authors }\end{array}$ & $\begin{array}{l}\text { Data } \\
\text { sample }\end{array}$ & Tested variables \\
\hline 2008 & $\begin{array}{l}\text { Ferrara } \text { et } \\
\text { al. }\end{array}$ & $\begin{array}{l}200 \\
\text { people }\end{array}$ & $\begin{array}{l}\text { Stress, depression, } \\
\text { disease connected with } \\
\text { caregivers stress }\end{array}$ \\
\hline 2017 & $\begin{array}{l}\text { De Cola } \\
\text { et al. }\end{array}$ & $\begin{array}{l}59 \\
\text { people }\end{array}$ & $\begin{array}{l}\text { 54 questions examining } \\
\text { how respondents felt } \\
\text { left out }\end{array}$ \\
\hline 2007 & $\begin{array}{l}\text { Steadman, } \\
\text { Tremont } \\
\text { and Davis }\end{array}$ & $\begin{array}{l}72 \\
\text { people }\end{array}$ & $\begin{array}{l}\text { Relationship } \\
\text { satisfaction }\end{array}$ \\
\hline 2017 & $\begin{array}{l}\text { Kaizik } \text { et } \\
\text { al }\end{array}$ & $\begin{array}{l}90 \\
\text { people }\end{array}$ & $\begin{array}{l}\text { Spousal and children } \\
\text { caregiver burden, } \\
\text { caregiver stress of } \\
\text { residing and non- } \\
\text { residing caregivers }\end{array}$ \\
\hline
\end{tabular}

Table 1: Summary of the existing researches on the subject of psychological distress of dementia caregivers

Table 1 presents a few studies which have similar objectives to the present thesis. The number of respondents varied from 59 people to 200 people. All of the mentioned scholarly works focused on evaluating to what extent the caregivers were experiencing distress, depression or had other mental and physical illnesses. Based on the studied literature, the author of the present thesis has developed her own objectives, chosen the means and tools of the study and have selected the research methodology, which are presented in the following two parts of the paper.

\section{Objectives}

As have been mentioned above, the present thesis has a general aim of evaluating the existence and severity of psychological distress among the caregivers who take care of dementia patients residing in Russia and Kazakhstan. From the aim of the paper, the following objectives can be deducted:

- To classify the existing knowledge on the studied topic in order to build a basis for the research;

- To construct a survey and collect primary data from the people whose life is directly affected and who are involved in caregiving in Russia and in Kazakhstan;

- To revise the collected data and present findings that answer the research question;

- To draw conclusions and offer recommendations for future studies in the area of psychological distress of the caregivers involved in supporting the dementia patients.

To sum up, the aim is to identify whether the chosen group of people suffer from caregiver burden or experience other forms of psychological distress. All of the objectives align with the general aim and are consequently worked through in a thesis paper. As for the following part of the thesis, it presents the main features of the data used in the research and the methodology employed to carry the research out.

\section{Material and Methods \\ Material}

The data for the analysis was collected using the digital survey portal Google Forms. There were 23 questions of different forms (multiple-choice, open-end questions and scale questions). The author created all of the questions herself. Two questions are designed to describe the demographic image of the respondents such as gender and age. The data is collected to examine to what extent the caregivers of dementia patients from Russia and Kazakhstan feel the caregiver burden and to what extent they feel abandoned. The choice of geographical location of the caregivers have been made based on two reasons. The first, there are online communities, whose members were willing to take part in the research and answer the questions. They live in both countries. As Kazakhstan and Russia have many commonalities in social and economic state, then the decision to include respondents from both countries have been made. Second, the surveys were conducted in Russian and all of the respondents spoke Russian language freely. As the author of the thesis paper speaks Russian fluently as well, there was no need in interpreting services.

Moreover, the questions are designed to reveal to what extent they are supported financially. At the end, the questionnaire contains an open-end question, which allows the respondents share any thought they may want to share related to the subject of the research.

It is important to point out that personal information was not collected, and the respondents were not paid. All of the respondents have voluntarily answered the questions of the questionnaire. This allows the author to assume that all of the answers were given in a sincere way. Moreover, as no personal information is revealed, there was no need to sign an informed consent form. The caregivers are referred to as Caregiver 1, Caregiver 2 and so on.

There were 52 respondents living in various regions of the 
Russian Federation and the Republic of Kazakhstan. Regarding the gender, only 3 out of 52 respondents were men. Their ages differed greatly being 24,43 and 67 . The 49 respondents were females. Their average age was 44.89 years and the median age was 45. The mode of the ages of female caregivers was not taken into account, as it would not add value to the analysis. The average age of females and males together was 44.88 , and the median age equalled 44 and 45 . The indices are quite similar as the quantity of male respondents is low. The following graph illustrates the distribution of caregiver ages divided groups with a 5-year-step.

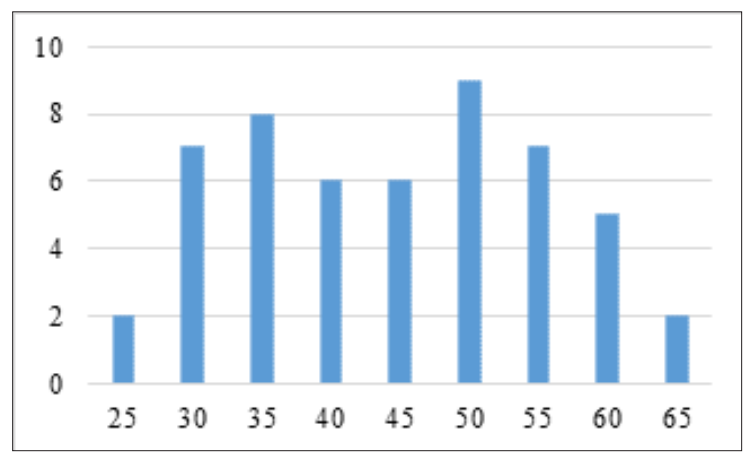

Figure 1: Number of respondents in age groups

It is evident that there are more than six people in each age group starting from 30 to 55 .

There are seven caregivers of 60 and over, and there are two caregivers of 25 and under.

The answers to the questionnaire is the main dataset that will be analysed to answer the main research questions. The tables in appendices B, C and D contain detailed answers of the respondents.

\section{Methods}

Qualitative research is a research which analyses non-numeric data in order to develop an understanding of the notions, attitudes, opinions, experiences and social phenomena. Compared to quantitative research, which works with numerical data and reveals the trends and patterns for existing or future phenomena, qualitative research allows the researcher gather and develop an insight that will broaden the research area for future studies. Qualitative research is widely used in psychology as it reveals the way studied group of people make sense of their experiences and the situation. The main purpose is to understand the situation from the perspective of the studied people or to understand how these people manage the issues and cope with the conditions arisen from the certain phenomenon. The conclusion in such research will reflect the real life situation in deeper and more profound way.

As an approach of the qualitative research, the author uses phenomenological research, which aims to appraise a phenomenon by investigating and interpreting subjective opinions and experiences of people living within the certain circumstances or a phenomenon (Heidegger, 2005). That is to say that in order to evaluate to what extent the caregivers are experiencing psychological distress, one would need to gather and analyze their perceptions, opinions, attitudes to the circumstances they live in.

As for the research methods, the present thesis will employ qualitative analysis based on a survey. This method will allow drawing conclusions from the conducted semi-structured analysis (Appendices). As the survey has options to choose from in some case and open questions, where respondents can answer using any amount of words, then the results are expected to provide answers reflecting the respondent experiences in-depth.

For the first part of the survey, where the answers are given in a form of predefined options, frequency and proportions will be analyzed across age groups, across number of years in caregiving and other parameters. This way, the author will attempt to find patterns in thinking of the respondent caregivers. For the part with open questions, all of the answers will be collected in one place, translated from Russian into English, and then categorized. For categorization, the author will code the meaningful sentences and code them using Microsoft Word and Excel functions.

In conclusion, according to the information provided above, the present thesis will employ qualitative research with phenomenological approach based on online surveys with mixed structure.

\section{Results and discussion}

The present part will display the core findings of the study carried out based on the methodology described above. The results will be presented without bias and in the order the questions are displayed in the survey. The questions will be grouped in order to deliver concise but informative findings. Respondents were asked to evaluate their current health state including mental and physical health. The results of the survey are displayed below:

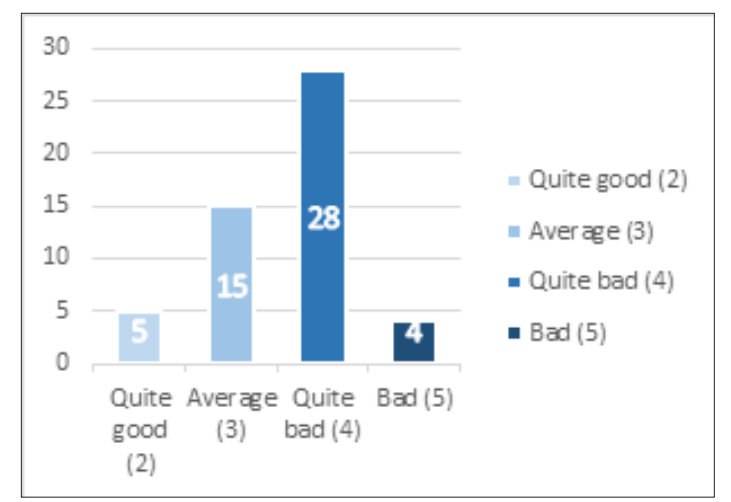




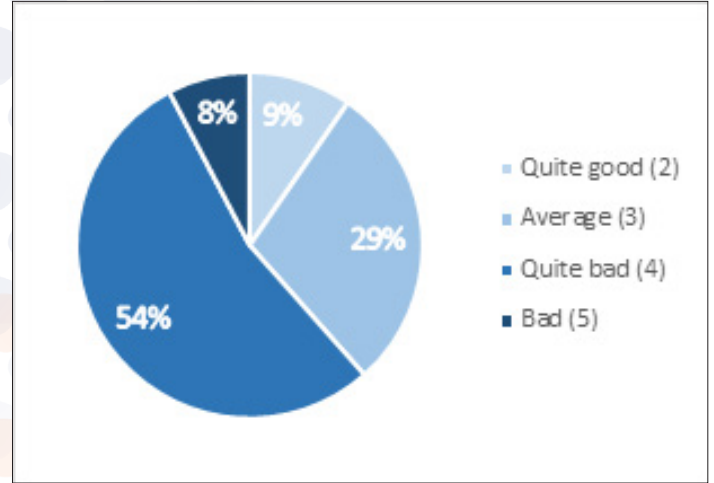

Figure 2: Self-evaluation of health state, quantity and percentage

The question asked respondents to choose from a scale an option that shows the state of their health. From the data, it becomes clear that twenty-eight people or $54 \%$ of respondents have indicated quite bad health state. Four respondents $(8 \%)$ thought their health was bad. Other 20 respondents thought that their health was average or quite good. The age and state of health was correlated using Microsoft Excel software, where the correlation coefficient was 0.02, which allows the author to conclude that the Simpson's paradox is not present in this case.
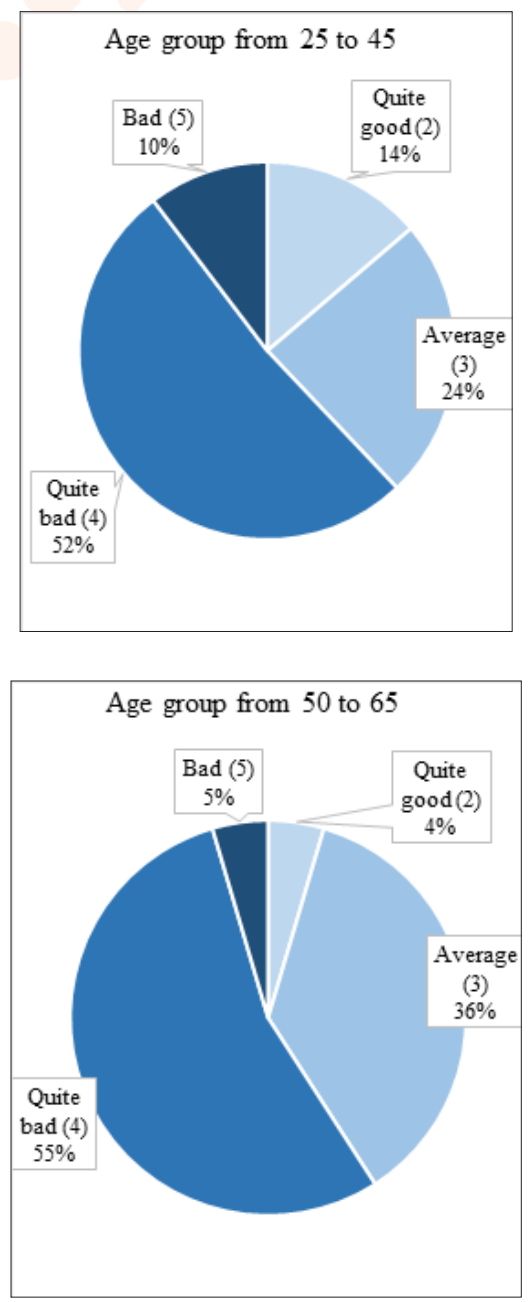

Figure 3: Self-evaluation of health state based on two age groups from 25 to 45 and from 50 to 65
As clearly seen from comparison of Figure 2 and 3, the general tendency is present and more than half are not satisfied with their health state regardless the age. Thus, one can assume that caregivers are generally not satisfied with their mental and physical health.

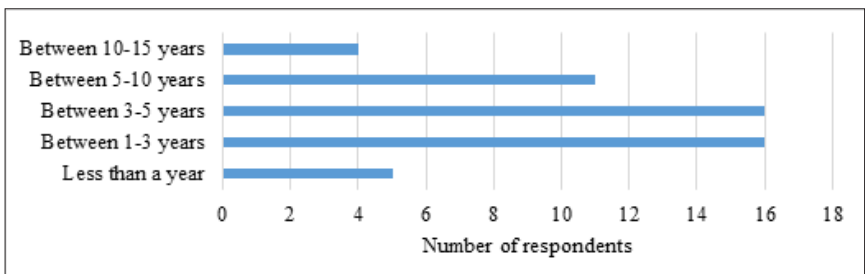

Figure 4: Number of years the respondents were involved in caregiving

As illustrated in Figure 4, the majority of respondents (31 people) have a caregiving experience of three or more years. Twenty-nine percent have five and more years of experience. Thus, the effect of caregiving on the level of psychological stress can be traced as these people have been engaged in the caregiving activities for a long time.

Answers behind the reason why people are engaged in caregiving were distributed in the following way:

\begin{tabular}{|l|l|l|}
\hline Options & $\begin{array}{l}\text { Number of } \\
\text { respondents }\end{array}$ & Share \\
\hline Familial sentiment & 46 & $87 \%$ \\
\hline A hired caregiver & 3 & $6 \%$ \\
\hline $\begin{array}{l}\text { There is nobody else except me } \\
\text { who will do it }\end{array}$ & 3 & $6 \%$ \\
\hline $\begin{array}{l}\text { Planning on inheriting the patient's } \\
\text { belongings }\end{array}$ & 1 & $2 \%$ \\
\hline
\end{tabular}

Table 2: Answers to question 5 of the survey

Eighty-seven percent of the respondents are engaged in caregiving because the patient is their relative. In three cases the patient is not only a relative, but also the caregiver is the only relative of the dementia patient. Thus, 49 caregivers out of 52 were related to the patient as a child caregiver or a spouse. In four cases or in $8 \%$ of the cases the caregiver was not related to the dementia patient. Three out of four were paid for their services, while one respondent had been promised to inherit the belongings of the patient after his death. To continue, 28 out of 52 respondents $(54 \%)$ were the only people who cared for the patient. This meant that these people were continuously in charge of taking care, running errands and managing the needs of the patients with dementia, and did not have time for themselves. For instance, 13 out of 28 worked full time along with being an only caregiver. All of these 13 respondents indicated that they did not receive any help from neither the state nor the charities. Moreover, seven out of these 13 respondents indicated that they feel stressed more than several times a day. Thus, $13.5 \%$ of the studied population indicated that they were the only person who cared for the patient. They did not receive any support and they were stressed during 
the daytime each day. What is more important, these people marked their health state being average or bad.

To continue, the proportion of people who were not the only caregiver for the patient was $46 \%$. The occupation of the respondents was distributed in the following shares (Figure 5).

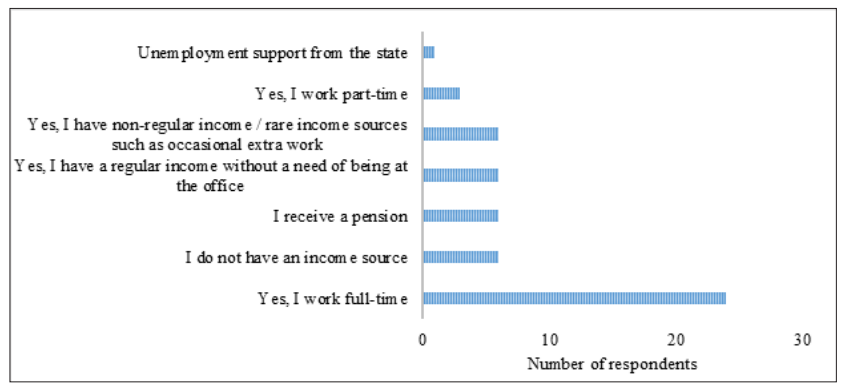

Figure 5: Occupation of the respondents

From the data displayed in Figure 5 it becomes clear that almost the half of the respondents are employed full time, which adds to the stress experienced from being a caregiver. The average self-assessment of the health state of these people was equal to 3.7 , which indicates that majority marked their health to be "bad" or "very bad".

Moreover, the table below indicates the answers of people employed full-time to questions 11 and 12 (Appendices A, C).

\begin{tabular}{|l|l|l|}
\hline & Yes & No \\
\hline Do you have enough money for your needs? & 11 & 13 \\
\hline $\begin{array}{l}\text { Do you have enough time to solve your own } \\
\text { problems / run errands? }\end{array}$ & 6 & 18 \\
\hline
\end{tabular}

Table 3: Answers to questions 11 and 12 by respondents employed full time

It is clear that more than half are not able to satisfy their own needs despite the fact that they are employed full-time. Moreover, 18 of 24 full-time working caregivers were unable to take care of their own problems.

Moreover, only two respondents felt minor stress. They either had no stress or experienced it only in several occasions during a month (Figure 6).

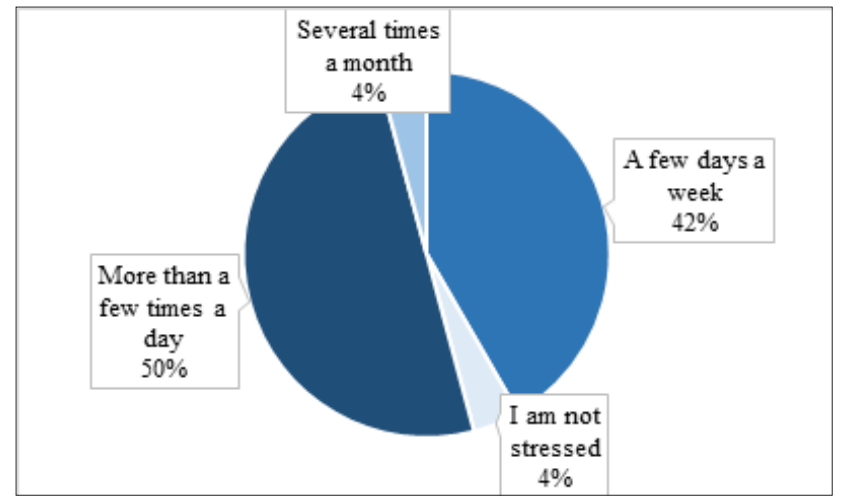

Figure 6: Frequency of experiencing stress by respondents employed full time
At the same time, the table proves how stressed the people can be if they are engaged in 24/7 caregiving to dementia patient and in 40 hours a week job. Fifty percent of the chosen respondents experienced stress during the day and $42 \%$ of the respondents were stressed during a week. This makes the proportion of the continuously stressed people equal to $92 \%$ of the working full-time respondents.

Moreover, six people were retired and served as a caregiver to their relatives. The frequency of experiencing stress was even higher for these respondents. Three people indicated that they were stressed several times a day, two of six were stressed few times a week and one respondent indicated that he was stressed constantly. Another caregiver who was constantly stressed was an unemployed caregiver, who received state funding due to an unemployment. Four respondents who were stressed during the day were unemployed and did not have an income source. Only one person out of all 52 respondents felt no stress during caregiving.

From the data displayed above, one can conclude that people who worked full working hours and had to take care of dementia patients and retired caregivers were stressed highly. Unemployed full time caregivers marked similar stress levels. As for part-time working or out-of office working caregivers, they have indicated moderate stress frequency (from several occasions a week to few times a month).

As for the existence of state support or support from charities or funds, six people have received state help as a caregiver, while only one caregiver received help from charities. This allows the author to conclude that neither state nor private organizations support caregivers residing in countries such as Russia and Kazakhstan. The caregivers, their needs and problems are ignored by the institutions, which also add to the stress levels of the named category of citizens.

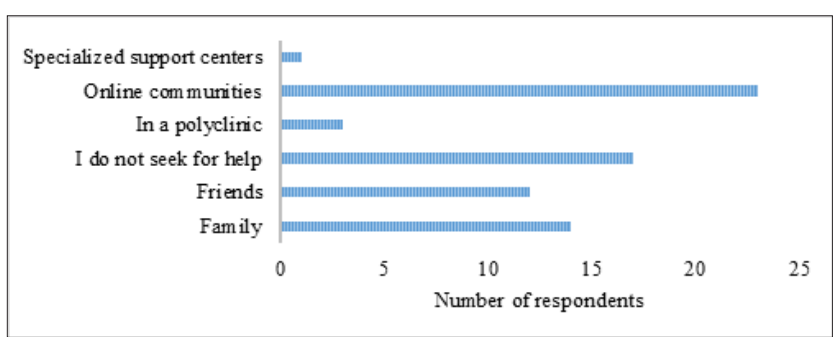

Figure 7: Where the respondents look for support

From the given information (Figure 7), it becomes clear that the caregivers do not know or do not have specialized support. Only one person has received specialized support. Fifty-two respondents have chosen 70 options. Thirty-seven percent receive information and support from friends and family, who are assumed to have none or minimal knowledge about the disease and the psychological distress caused by it. Thirtythree percent search for information and support online and $24 \%$ of the caregivers deal with their problems themselves. This means that no institutional organized support is available for the people engaged in continuous caregiving activities. Taking into account the fact that almost none of them receive 
financial support, the high stress levels are reasonable.

The questions 14-20 were constructed in a way to evaluate the severity of stress, the causes of stress and the opinions of the respondents on the situation they are in. The questions and answers are presented in Appendices A and C. For the analysis, the following table has been constructed in order to understand what the scale meant for the respondents.

\begin{tabular}{|l|l|l|}
\hline $\begin{array}{l}\text { Main focus of the } \\
\text { question }\end{array}$ & Meaning of 1 & Meaning of 10 \\
\hline $\begin{array}{l}\text { Experiencing } \\
\text { stress }\end{array}$ & No stress & Severe stress \\
\hline Tiredness & Not tired & Severe tiredness \\
\hline $\begin{array}{l}\text { Expectations } \\
\text { for future } \\
\text { improvement }\end{array}$ & Optimistic & Pessimistic \\
\hline $\begin{array}{l}\text { Dementia } \\
\text { symptoms } \\
\text { influence (not } \\
\text { recognizing) }\end{array}$ & Does not affect & $\begin{array}{l}\text { Affects (saddens) } \\
\text { greatly }\end{array}$ \\
\hline $\begin{array}{l}\text { Obligation to care } \\
\text { rather a desire }\end{array}$ & $\begin{array}{l}\text { More desire } \\
\text { than obligation }\end{array}$ & $\begin{array}{l}\text { More obligation } \\
\text { than desire }\end{array}$ \\
\hline $\begin{array}{l}\text { Angry at patient } \\
\text { for being sick }\end{array}$ & Not angry & Very angry \\
\hline $\begin{array}{l}\text { Breaking on at } \\
\text { others sue to stress }\end{array}$ & Rarely & Frequently \\
\hline
\end{tabular}

Table 4: Scales for the questions 14-20 and their interpretation

Thus, the greater the number, the greater the stress is experienced by the respondent. The average for each caregiver has been calculated and presented in the bar chart below (Figure 8). It is evident from the bar chart that the number of people who have reported minimal stress levels or negative emotions from caregiving is extremely low. Three people had minimal stress (average 1 and 2 for all answers). Ten people's answers prove their stress levels to be average.

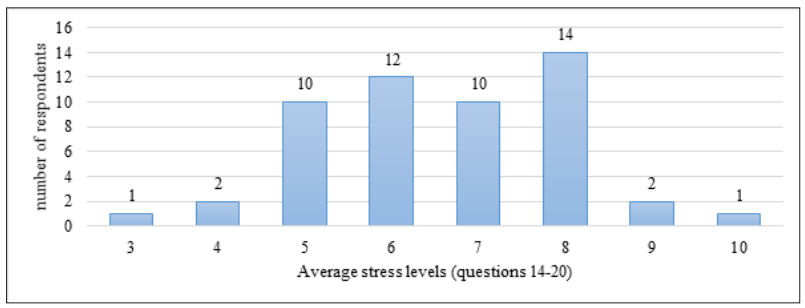

Figure 8: Number of respondents with various stress levels (average)

At the same time, other 39 respondents had experienced from average to severe stress. Most of the respondents have marked 6,7 and 8 out of 10 , which is the highest possible level of stress included in the survey responses. Three respondents were severely stressed according to the survey.

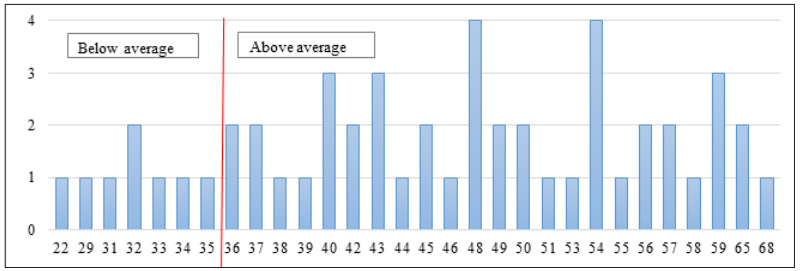

Figure 9: further investigates the psychological stress experienced by the respondents.

Only a minority of respondents have answered the questions from 14 to 20 in a positive way, indicating low stress levels. Despite that, their total count for seven questions ranged from 22 to 35 . In other words, their average mark was from 3 to 5. However, as it is evident from Figure 9, the majority have experienced stress and stress related issues severely. The total count for them for questions 14-20 varied from 36 to 68. Thus, the study of the survey results reveals the signs of severe stress in the majority of the respondents.

\section{Limitations}

The present thesis paper has some limitations that occurred due to Covid-19 pandemic consequences. Due to inconstant sanitary rules, the author was not able to meet the respondents in person in order to interview them. Moreover, the stress experienced by the respondents may be partially influenced by the lockdown and from the psychosis connected with the Covid-19 related concerns. However, the author does not include any of that into the research and has warned the respondents to avoid mentioning the Covid-19 related mental problems if that was possible.

\section{Bias}

The author has reconsidered the content of the survey questions in order to avoid design bias. That is to say, there was no purpose to convince the respondents to prove the author's point in purpose. Moreover, there was no participant bias, as all of the respondents took part in the survey voluntarily. Moreover, the author is aware about the analysis bias. Thus, she carried out the analysis without bias and with an aim of developing and delivering a properly conducted research.

\section{Conclusion}

In conclusion, the present thesis has examined the existence of psychological stress of caregivers for Dementia Patients residing in Russia and Kazakhstan. In this regard, 52 people living in the named circumstances were surveyed in order to find out if these people suffer from distress and what are the main causes of the stress. Moreover, the author aimed to find out to what extent the caregivers are supported by the governments or charities. All of the objectives were achieved and the author was able to conclude that majority of the respondents felt stressed from few times a day to few times a week. Moreover, the intensity of their stress was from average to high.

The importance of the present thesis is in evaluating the extent of the problem in two countries. The findings of the present thesis can be used by scholars to receive an insight regarding 
the caregivers of CIS counties, and could be used by specialised caregiver support centres.

\section{References}

1. Alzheimer's Association. (n.d.). Taking care of yourself. https://www.alz.org/help-support/i-have-alz/live-well/ taking-care-of-yourself.

2. Berg-Weger, M., \& Tebb, S. (2003). Conversations with Researchers About Family Caregiving: Trends and Future Directions. Generations: Journal of the American Society on Aging, 27(4), 9-16. Retrieved May 3, 2021, from https://www.jstor.org/stable/26555262

3. Braun, V., \& Clarke, V. (2006). Using thematic analysis in psychology. Qualitative research in psychology, 3(2), 77-101.

4. Braun, V., Clarke, V., Boulton, E., Davey, L., \& McEvoy, C. (2020). The online survey as a qualitative research tool. International Journal of Social Research Methodology, $1-14$.

5. Camic, P. M., Rhodes, J. E., \& Yardley, L. E. (2003). Qualitative research in psychology: Expanding perspectives in methodology and design. American Psychological Association.

6. Cheng, S. (2017). Dementia Caregiver Burden: a Research Update and Critical Analysis. Current Psychiatry Reports, 19(9). doi: 10.1007/s11920-017-0818-2

7. Chiu, T., Marziali, E., Colantonio, A., Carswell, A., Gruneir, M., Tang, M., \& Eysenbach, G. (2009). InternetBased Caregiver Support for Chinese Canadians Taking Care of a Family Member with Alzheimer Disease and Related Dementia. Canadian Journal On Aging / La Revue Canadienne Du Vieillissement, 28(4), 323-336. doi: 10.1017/s0714980809990158

8. Coen, R. F., Swanwick, G. R., O’boyle, C. A., \& Coakley, D. (1997). Behaviour disturbance and other predictors of carer burden in Alzheimer's disease. International Journal of Geriatric Psychiatry, 12(3), 331-336.

9. Drebing, C., McCarty, E. F., \& Lombardo, N. B. E. (2002). Professional caregivers for patients with dementia: Predictors of job and career commitment. American Journal of Alzheimer's Disease \& Other Dementias, 17(6), 357-366.

10. Ferrara, M., Langiano, E., Di Brango, T., De Vito, E., Di Cioccio, L., \& Bauco, C. (2008). Prevalence of stress, anxiety and depression in with Alzheimer caregivers. Health And Quality Of Life Outcomes, 6(1), 93. doi: 10.1186/1477-7525-6-93

11. Gibson, R. H., Gander, P. H., \& Jones, L. M. (2014). Understanding the sleep problems of people with dementia and their family caregivers. Dementia, 13(3), 350-365.

12. Groenewald, T. (2004). A phenomenological research design illustrated. International journal of qualitative methods, 3(1), 42-55.

13. Heidegger, M. (2005). Introduction to phenomenological research. Indiana university press.

14. Husserl, E. (1999). The essential Husserl: Basic writings in transcendental phenomenology. Indiana University Press.
15. Kaizik, C., Caga, J., Camino, J., O’Connor, C. M., McKinnon, C., Oyebode, J. R., ... \& Mioshi, E. (2017). Factors underpinning caregiver burden in frontotemporal dementia differ in spouses and their children. Journal of Alzheimer's Disease, 56(3), 1109-1117.

16. Kales, H., Gitlin, L., \& Lyketsos, C. (2014). The Time Is Now to Address Behavioral Symptoms of Dementia. Generations: Journal of the American Society on Aging, 38(3), 86-95. Retrieved May 4, 2021, from https://www. jstor.org/stable/26556065

17. Lin, W., Tsai, C., Wang, S., Hwang, J., \& Fuh, J. (2012). Comparison of the burdens of family caregivers and foreign paid caregivers of the individuals with dementia. International Psychogeriatrics, 24(12), 1953-1961. doi: 10.1017/s1041610212001354

18. Maxwell, J. A. (2012). Qualitative research design: An interactive approach (Vol. 41). Sage publications.

19. Sgier, L. (2012). Qualitative data analysis. An Initiat. Gebert Ruf Stift, 19, 19-21.

20. Steadman, L. P., Tremont, G., \& Duncan Davis, J. (2007). Premorbid relationship satisfaction and caregiver burden in dementia caregivers. Journal of geriatric psychiatry and neurology, 20(2), 115-119.

21. Leggett, A., Polenick, C. A., Maust, D. T., \& Kales, H. C. (2018). "What Hath Night to Do with Sleep?": The caregiving context and dementia caregivers' nighttime awakenings. Clinical gerontologist, 41(2), 158-166.

22. LoboPrabhu, S.M., Molinari, V.A., \& Lomax, J.W. (2006). Supporting the Caregiver in Dementia: A Guide for Health Care Professionals. Baltimore: Johns Hopkins University Press., doi:10.1353/book.3234.

23. Logsdon, R. G., McCurry, S. M., \& Teri, L. (2007). Evidence-based psychological treatments for disruptive behaviors in individuals with dementia. Psychology and aging, 22(1), 28.

24. Oken, B. S., Fonareva, I., \& Wahbeh, H. (2011). Stressrelated cognitive dysfunction in dementia caregivers. Journal of geriatric psychiatry and neurology, 24(4), 191-198. https://doi.org/10.1177/0891988711422524

25. Podgorski, C., \& King, D. (2009). Losing Function, Staying Connected: Family Dynamics in Provision of Care for People with Dementia. Generations: Journal of the American Society on Aging, 33(1), 24-29. Retrieved May 3, 2021, from https://www.jstor.org/stable/26555629

26. Relojo-Howell, D. (2020, September 11). Grieving before death: Breaking down anticipatory grief. Psychreg. https://www.psychreg.org/anticipatory-grief.

27. Sullivan, C., \& Forrester, M. A. (Eds.). (2018). Doing qualitative research in psychology: A practical guide. Sage.

28. Sweeting, H. N., \& Gilhooly, M. L. (1990). Anticipatory grief: A review. Social Science \& Medicine, 30(10), 10731080.

29. World Health Organization. (2021). Dementia. World Health Organization. https://www.who.int/news-room/ fact-sheets/detail/dementia.

30. World Health Organization. (n.d.). Priority setting for research on mental health. World Health Organization. 
https://www.who.int/observatories/global-observatoryon-health-research-and-development/analyses-andsyntheses/mental-health/priority-setting-for-research-onmental-health.

31. Willig, C. (2013). Introducing qualitative research in psychology. McGraw-hill education (UK).

32. Zwerling, J., Cohen, J., \& Verghese, J. (2021). Dementia and caregiver stress. Retrieved 12 April 2021, from

\section{$\underline{\text { Appendix A }}$}

Survey questions

1. Indicate your gender
a. Male
b. Female

2. Indicate your age rounded to the full years

3. On a scale from one to five subjectively rate your health state, where 1 is "bad, I need a medical care" and 5 is "I am absolutely healthy".

4. How long have you been taking care of a patient with dementia?
a. Less than a year
b. Between 1-3 years
c. Between 3-5 years
d. Between 5-10 years
e. Between 10-15 years
f. More than 15 years

5. What is the main reason why you care for a patient with dementia?
a. Familial sentiment
b. I am a hired caregiver
c. There is nobody else except me who will do it
d. I am planning on inheriting the patient's flat and belongings
e. Other answer*

6. Are you the only person who takes care of a patient with dementia?
a. Yes
b. No

7. Do you work? Do you have an income?
a. Yes, I work full-time
b. Yes, I work part-time
c. Yes, I have a regular income without a need of being at the office
d. Yes, I have non-regular income / rare income sources such as occasional extra work
e. I do not have an income source
f. Other answer*

8. Do you receive any support from the state as a person who cares for a person with dementia?
a. Yes
b. No

9. Do you receive any support from charities?
a. Yes
b. No

10. How much money you spend on a patient's needs?

11. Do you have enough money for your needs?
a. Yes
b. No

12. 12. Do you have enough time to solve your own problems / run errands?
a. Yes
b. No
c. Other answer*

13. How often do you experience stress?
a. More than a few times a day
b. A few days a week
c. Several times a month
d. I am not stressed
e. Other answer*

\begin{tabular}{|c|c|c|c|}
\hline $\begin{array}{l}10 \text { scale } \\
\text { questions }\end{array}$ & $\begin{array}{l}\text { Evaluate the } \\
\text { following from } 1 \\
\text { to } 10\end{array}$ & Meaning of 1 & $\begin{array}{l}\text { Meaning of } \\
10\end{array}$ \\
\hline 14 & $\begin{array}{l}\text { Experiencing } \\
\text { stress }\end{array}$ & No stress & Severe stress \\
\hline 15 & Tiredness & Not tired & $\begin{array}{l}\mathrm{S} \text { e } \mathrm{v} \text { e } \mathrm{r} \text { e } \\
\text { tiredness }\end{array}$ \\
\hline 16 & $\begin{array}{l}\text { Expectations } \\
\text { for future } \\
\text { improvement }\end{array}$ & Disagree & Agree \\
\hline 17 & $\begin{array}{l}\mathrm{D} \text { e } \mathrm{m} \text { e } \mathrm{n} \mathrm{t} \mathrm{i} a \\
\mathrm{~s} \text { y } \mathrm{p} \mathrm{t} \text { o } \mathrm{m} \mathrm{s} \\
\text { influence (not } \\
\text { recognizing) }\end{array}$ & Disagree & Agree \\
\hline 18 & $\begin{array}{ll}\text { Obligation to } \\
\text { care rather a } \\
\text { desire }\end{array}$ & Disagree & Agree \\
\hline 19 & $\begin{array}{l}\text { Angry for being } \\
\text { sick }\end{array}$ & Disagree & Agree \\
\hline 20 & $\begin{array}{l}\text { To be irritated at } \\
\text { others }\end{array}$ & Disagree & Agree \\
\hline
\end{tabular}

21. Where do you get counselling/psychological help? (multiple choices can be selected)
a. Friends/Friends
b. Family members
c. In the polyclinic/hospital
d. Online Communities
e. In specialized centers
f. I do not seek for help
g. Other answer* 
The survey answers $-1^{\text {st }}$ part

\section{Appendix B}

\begin{tabular}{|c|c|c|c|c|c|c|c|c|c|c|c|}
\hline Caregiver & Q1 & Q2 & Q3 & $\begin{array}{l}\text { Q4 } \\
\min \end{array}$ & $\begin{array}{l}\text { Q4 } \\
\max \end{array}$ & Q5 & Q6 & Q7 & Q8 & Q9 & Q10 in Rub \\
\hline Caregiver 1 & Female & 35 & 4 & 3 & 5 & $\begin{array}{l}\text { Familial } \\
\text { sentiment }\end{array}$ & No & $\begin{array}{l}\text { Yes, I work } \\
\text { full-time }\end{array}$ & No & No & 5000 \\
\hline Caregiver 2 & Female & 34 & 2 & 5 & 10 & $\begin{array}{l}\text { I am a hired } \\
\text { caregiver }\end{array}$ & No & $\begin{array}{l}\text { Yes, I work } \\
\text { full-time }\end{array}$ & No & No & 35000 \\
\hline Caregiver 3 & Female & 57 & 4 & 10 & 15 & $\begin{array}{l}\text { Familial } \\
\text { sentiment }\end{array}$ & Yes & $\begin{array}{l}\text { Yes, I work } \\
\text { full-time }\end{array}$ & No & No & 40000 \\
\hline Caregiver 4 & Female & 57 & 3 & 10 & 15 & $\begin{array}{l}\text { Familial } \\
\text { sentiment }\end{array}$ & Yes & $\begin{array}{l}\text { I receive a } \\
\text { pension }\end{array}$ & No & No & 15000 \\
\hline Caregiver 5 & Female & 51 & 4 & 3 & 5 & $\begin{array}{l}\text { Familial } \\
\text { sentiment }\end{array}$ & No & $\begin{array}{l}\text { Yes, I work } \\
\text { full-time }\end{array}$ & No & No & $\begin{array}{l}\text { The pension of } \\
\text { the dementia } \\
\text { patient covers the } \\
\text { expenses }\end{array}$ \\
\hline Caregiver 6 & Female & 32 & 3 & 5 & 10 & $\begin{array}{l}\text { There is } \\
\text { nobody else } \\
\text { except me } \\
\text { who will } \\
\text { do it }\end{array}$ & Yes & $\begin{array}{l}\text { Yes, I work } \\
\text { part-time }\end{array}$ & No & No & 12500 \\
\hline Caregiver 7 & Female & 44 & 2 & 10 & 15 & $\begin{array}{l}\text { Familial } \\
\text { sentiment }\end{array}$ & Yes & $\begin{array}{l}\text { I do not have } \\
\text { an income } \\
\text { source }\end{array}$ & Yes & No & 30000 \\
\hline Caregiver 8 & Female & 44 & 4 & 1 & 3 & $\begin{array}{l}\text { Familial } \\
\text { sentiment }\end{array}$ & Yes & $\begin{array}{l}\text { Yes, I have } \\
\text { non-regular } \\
\text { income / } \\
\text { rare income } \\
\text { sources such } \\
\text { as occasional } \\
\text { extra work }\end{array}$ & No & No & 20000 \\
\hline Caregiver 9 & Female & 44 & 3 & 1 & 3 & $\begin{array}{l}\text { Familial } \\
\text { sentiment }\end{array}$ & Yes & $\begin{array}{l}\text { Yes, I work } \\
\text { full-time }\end{array}$ & No & No & I do not count \\
\hline Caregiver 10 & Female & 27 & 3 & 3 & 5 & $\begin{array}{l}\text { Familial } \\
\text { sentiment }\end{array}$ & No & $\begin{array}{l}\text { Yes, I have a } \\
\text { regular income } \\
\text { without a need } \\
\text { of being at the } \\
\text { office }\end{array}$ & No & No & 20000 \\
\hline Caregiver 11 & Female & 48 & 4 & 10 & 15 & $\begin{array}{l}\text { Familial } \\
\text { sentiment }\end{array}$ & Yes & $\begin{array}{l}\text { Yes, I have a } \\
\text { regular income } \\
\text { without a need } \\
\text { of being at the } \\
\text { office }\end{array}$ & No & No & 25000 \\
\hline Caregiver 12 & Female & 63 & 4 & 1 & 3 & $\begin{array}{l}\text { Familial } \\
\text { sentiment }\end{array}$ & No & $\begin{array}{l}\text { I receive a } \\
\text { pension }\end{array}$ & No & Yes & 30000 \\
\hline Caregiver 13 & Female & 34 & 4 & 1 & 3 & $\begin{array}{l}\text { Familial } \\
\text { sentiment }\end{array}$ & No & $\begin{array}{l}\text { Yes, I work } \\
\text { full-time }\end{array}$ & No & No & 15000 \\
\hline Caregiver 14 & Female & 57 & 3 & 1 & 3 & $\begin{array}{l}\text { Familial } \\
\text { sentiment }\end{array}$ & Yes & $\begin{array}{l}\text { I receive a } \\
\text { pension }\end{array}$ & No & No & I do not count \\
\hline
\end{tabular}




\begin{tabular}{|c|c|c|c|c|c|c|c|c|c|c|c|}
\hline Caregiver 15 & Female & 35 & 4 & 3 & 5 & $\begin{array}{l}\text { There is } \\
\text { nobody else } \\
\text { except me } \\
\text { who will } \\
\text { do it }\end{array}$ & No & $\begin{array}{l}\text { Yes, I work } \\
\text { full-time }\end{array}$ & No & No & 30000 \\
\hline Caregiver 16 & Female & 58 & 4 & 5 & 10 & $\begin{array}{l}\text { Familial } \\
\text { sentiment, } \\
\text { inheritance, } \\
\text { payment after } \\
\text { the patient's } \\
\text { death }\end{array}$ & Yes & $\begin{array}{l}\text { I receive a } \\
\text { pension }\end{array}$ & No & No & 17000 \\
\hline Caregiver 17 & Female & 59 & 4 & 3 & 5 & $\begin{array}{l}\text { Familial } \\
\text { sentiment }\end{array}$ & No & $\begin{array}{l}\text { I receive a } \\
\text { pension }\end{array}$ & No & No & 22500 \\
\hline Caregiver 18 & Female & 51 & 4 & 0 & 1 & $\begin{array}{l}\text { Familial } \\
\text { sentiment }\end{array}$ & No & $\begin{array}{l}\text { Yes, I work } \\
\text { full-time }\end{array}$ & No & No & 12000 \\
\hline Caregiver 19 & Male & 24 & 4 & 3 & 5 & $\begin{array}{l}\text { Familial } \\
\text { sentiment }\end{array}$ & No & $\begin{array}{l}\text { Yes, I have } \\
\text { non-regular } \\
\text { income / } \\
\text { rare income } \\
\text { sources such } \\
\text { as occasional } \\
\text { extra work }\end{array}$ & No & No & 17000 \\
\hline Caregiver 20 & Female & 47 & 2 & 5 & 10 & $\begin{array}{l}\text { There is } \\
\text { nobody else } \\
\text { except me } \\
\text { who will } \\
\text { do it }\end{array}$ & Yes & $\begin{array}{l}\text { I do not have } \\
\text { an income } \\
\text { source }\end{array}$ & No & No & 17000 \\
\hline Caregiver 21 & Female & 32 & 3 & 1 & 3 & $\begin{array}{l}\text { Familial } \\
\text { sentiment }\end{array}$ & Yes & $\begin{array}{l}\text { Yes, I work } \\
\text { full-time }\end{array}$ & No & No & 20000 \\
\hline Caregiver 22 & Female & 58 & 5 & 1 & 3 & $\begin{array}{l}\text { Familial } \\
\text { sentiment }\end{array}$ & Yes & $\begin{array}{l}\text { Yes, I have a } \\
\text { regular income } \\
\text { without a need } \\
\text { of being at the } \\
\text { office }\end{array}$ & No & No & I do not count \\
\hline Caregiver 23 & Female & 50 & 3 & 1 & 3 & $\begin{array}{l}\text { Familial } \\
\text { sentiment }\end{array}$ & Yes & $\begin{array}{l}\text { Yes, I work } \\
\text { full-time }\end{array}$ & No & No & 25000 \\
\hline Caregiver 24 & Female & 47 & 3 & 5 & 10 & $\begin{array}{l}\text { Familial } \\
\text { sentiment }\end{array}$ & No & $\begin{array}{l}\text { I do not have } \\
\text { an income } \\
\text { source }\end{array}$ & No & No & $\begin{array}{l}\text { The pension of } \\
\text { the dementia } \\
\text { patient covers the } \\
\text { expenses }\end{array}$ \\
\hline Caregiver 25 & Female & 50 & 3 & 1 & 3 & $\begin{array}{l}\text { Familial } \\
\text { sentiment }\end{array}$ & Yes & $\begin{array}{l}\text { Yes, I work } \\
\text { full-time }\end{array}$ & No & No & 10000 \\
\hline Caregiver 26 & Female & 35 & 2 & 3 & 5 & $\begin{array}{l}\text { Familial } \\
\text { sentiment }\end{array}$ & No & $\begin{array}{l}\text { Yes, I work } \\
\text { full-time }\end{array}$ & No & No & 10000 \\
\hline Caregiver 27 & Female & 39 & 4 & 1 & 3 & $\begin{array}{l}\text { Familial } \\
\text { sentiment }\end{array}$ & Yes & $\begin{array}{l}\text { Yes, I work } \\
\text { full-time }\end{array}$ & No & No & 30000 \\
\hline Caregiver 28 & Female & 41 & 4 & 5 & 10 & $\begin{array}{l}\text { Familial } \\
\text { sentiment }\end{array}$ & Yes & $\begin{array}{l}\text { Yes, I work } \\
\text { full-time }\end{array}$ & No & No & 20000 \\
\hline Caregiver 29 & Male & 43 & 5 & 3 & 5 & $\begin{array}{l}\text { Familial } \\
\text { sentiment }\end{array}$ & No & $\begin{array}{l}\text { Yes, I have a } \\
\text { regular income } \\
\text { without a need } \\
\text { of being at the } \\
\text { office }\end{array}$ & No & No & 20000 \\
\hline
\end{tabular}




\begin{tabular}{|c|c|c|c|c|c|c|c|c|c|c|c|}
\hline Caregiver 30 & Female & 41 & 5 & 1 & 3 & $\begin{array}{l}\text { Familial } \\
\text { sentiment }\end{array}$ & Yes & $\begin{array}{l}\text { Yes, I work } \\
\text { full-time }\end{array}$ & No & No & 5000 \\
\hline Caregiver 31 & Female & 53 & 4 & 3 & 5 & $\begin{array}{l}\text { Familial } \\
\text { sentiment }\end{array}$ & Yes & $\begin{array}{l}\text { Yes, I work } \\
\text { full-time }\end{array}$ & No & No & 15000 \\
\hline Caregiver 32 & Female & 42 & 3 & 3 & 5 & $\begin{array}{l}\text { Familial } \\
\text { sentiment }\end{array}$ & Yes & $\begin{array}{l}\text { I do not have } \\
\text { an income } \\
\text { source }\end{array}$ & No & No & 15000 \\
\hline Caregiver 33 & Female & 28 & 4 & 3 & 5 & $\begin{array}{l}\text { Familial } \\
\text { sentiment }\end{array}$ & Yes & $\begin{array}{l}\text { I sell my } \\
\text { belongings } \\
\text { through an } \\
\text { online market }\end{array}$ & No & No & 12000 \\
\hline Caregiver 34 & Female & 55 & 4 & 5 & 10 & $\begin{array}{l}\text { Familial } \\
\text { sentiment }\end{array}$ & No & $\begin{array}{l}\text { Yes, I work } \\
\text { full-time }\end{array}$ & Yes & No & 25000 \\
\hline Caregiver 35 & Female & 48 & 3 & 1 & 3 & $\begin{array}{l}\text { Familial } \\
\text { sentiment }\end{array}$ & Yes & $\begin{array}{l}\text { Yes, I have a } \\
\text { regular income } \\
\text { without a need } \\
\text { of being at the } \\
\text { office }\end{array}$ & No & No & 50000 \\
\hline Caregiver 36 & Female & 37 & 5 & 0 & 1 & $\begin{array}{l}\text { I am a hired } \\
\text { caregiver }\end{array}$ & No & $\begin{array}{l}\text { Yes, I work } \\
\text { full-time }\end{array}$ & Yes & No & 9000 \\
\hline Caregiver 37 & Female & 28 & 4 & 1 & 3 & $\begin{array}{l}\text { Familial } \\
\text { sentiment }\end{array}$ & No & $\begin{array}{l}\text { Yes, I work } \\
\text { part-time }\end{array}$ & No & No & 30000 \\
\hline Caregiver 38 & Female & 65 & 4 & 5 & 10 & $\begin{array}{l}\text { Familial } \\
\text { sentiment }\end{array}$ & Yes & $\begin{array}{l}\text { Yes, I work } \\
\text { part-time }\end{array}$ & No & No & 7000 \\
\hline Caregiver 39 & Female & 48 & 2 & 1 & 3 & $\begin{array}{l}\text { Familial } \\
\text { sentiment }\end{array}$ & Yes & $\begin{array}{l}\text { I do not work, } \\
\text { but my mother } \\
\text { supports me } \\
\text { financially }\end{array}$ & No & No & $\begin{array}{l}\text { All of my income } \\
\text { goes to a patient } \\
\text { support }\end{array}$ \\
\hline Caregiver 40 & Male & 67 & 3 & 3 & 5 & $\begin{array}{l}\text { Familial } \\
\text { sentiment }\end{array}$ & No & $\begin{array}{l}\text { Yes, I have a } \\
\text { regular income } \\
\text { without a need } \\
\text { of being at the } \\
\text { office }\end{array}$ & No & No & 20000 \\
\hline Caregiver 41 & Female & 28 & 4 & 1 & 3 & $\begin{array}{l}\text { Familial } \\
\text { sentiment }\end{array}$ & No & $\begin{array}{l}\text { Yes, I work } \\
\text { full-time }\end{array}$ & No & No & 15000 \\
\hline Caregiver 42 & Female & 52 & 4 & 3 & 5 & $\begin{array}{l}\text { Familial } \\
\text { sentiment }\end{array}$ & Yes & $\begin{array}{l}\text { Yes, I work } \\
\text { full-time }\end{array}$ & No & No & 22000 \\
\hline Caregiver 43 & Female & 38 & 4 & 1 & 3 & $\begin{array}{l}\text { Familial } \\
\text { sentiment }\end{array}$ & No & $\begin{array}{l}\text { I do not have } \\
\text { an income } \\
\text { source }\end{array}$ & No & No & 15000 \\
\hline Caregiver 44 & Female & 58 & 3 & 3 & 5 & $\begin{array}{l}\text { I am a hired } \\
\text { caregiver }\end{array}$ & Yes & $\begin{array}{l}\text { Yes, I work } \\
\text { full-time }\end{array}$ & No & No & $\begin{array}{l}\text { The pension of } \\
\text { the dementia } \\
\text { patient covers the } \\
\text { expenses }\end{array}$ \\
\hline Caregiver 45 & Female & 56 & 3 & 3 & 5 & $\begin{array}{l}\text { Familial } \\
\text { sentiment }\end{array}$ & Yes & $\begin{array}{l}\text { Unemployment } \\
\text { support from } \\
\text { the state }\end{array}$ & Yes & No & 20000 \\
\hline Caregiver 46 & Female & 56 & 4 & 5 & 10 & $\begin{array}{l}\text { Familial } \\
\text { sentiment }\end{array}$ & Yes & $\begin{array}{l}\text { Yes, I work } \\
\text { full-time }\end{array}$ & No & No & 20000 \\
\hline
\end{tabular}




\begin{tabular}{|l|l|l|l|l|l|l|l|l|l|l|l|}
\hline Caregiver 47 & Female & 32 & 4 & 5 & 10 & $\begin{array}{l}\text { Familial } \\
\text { sentiment }\end{array}$ & Yes & $\begin{array}{l}\text { Yes, I have } \\
\text { non-regular } \\
\text { income / } \\
\text { rare income } \\
\text { sources such } \\
\text { as occasional } \\
\text { extra work }\end{array}$ & No & No & 25000 \\
\hline Caregiver 48 & Female & 35 & 4 & 0 & 1 & $\begin{array}{l}\text { Familial } \\
\text { sentiment }\end{array}$ & Yes & $\begin{array}{l}\text { Yes, I work } \\
\text { full-time }\end{array}$ & No & No & 15000 \\
\hline Caregiver 49 & Female & 36 & 4 & 5 & 10 & $\begin{array}{l}\text { Familial } \\
\text { sentiment }\end{array}$ & No & $\begin{array}{l}\text { Yes, I have } \\
\text { non-regular } \\
\text { income / } \\
\text { rare income } \\
\text { sources such } \\
\text { as occasional } \\
\text { extra work }\end{array}$ & Yes & No & $250 \$$ \\
\hline Caregiver 50 & Female & 33 & 3 & 0 & 1 & $\begin{array}{l}\text { Familial } \\
\text { sentiment }\end{array}$ & No & $\begin{array}{l}\text { I do not have } \\
\text { an income } \\
\text { source }\end{array}$ & No & No & $\begin{array}{l}\text { The pension of } \\
\text { the dementia } \\
\text { patient covers the } \\
\text { expenses }\end{array}$ \\
\hline Caregiver 51 & Female & 45 & 4 & 3 & 5 & $\begin{array}{l}\text { Familial } \\
\text { sentiment }\end{array}$ & No & $\begin{array}{l}\text { Yes, I work } \\
\text { full-time }\end{array}$ & No & No & 30000 \\
\hline Caregiver 52 & Female & 57 & 4 & 0 & 1 & $\begin{array}{l}\text { Familial } \\
\text { sentiment }\end{array}$ & Yes & $\begin{array}{l}\text { I receive a } \\
\text { pension }\end{array}$ & No & No & 20000 \\
\hline
\end{tabular}

The survey answers $-2^{\text {nd }}$ part

\section{$\underline{\text { Appendix } \mathrm{C}}$}

\begin{tabular}{|l|l|l|l|l|l|l|l|l|l|l|l|}
\hline Caregiver & Q11 & Q12 & Q13 & Q14 & Q15 & Q16 & Q17 & Q18 & Q19 & Q20 & Q21 \\
\hline Caregiver 1 & No & No & $\begin{array}{l}\text { A few days a } \\
\text { week }\end{array}$ & 7 & 10 & 8 & 7 & 2 & 3 & 8 & I do not seek for help \\
\hline Caregiver 2 & No & No & $\begin{array}{l}\text { More than a } \\
\text { few times a day }\end{array}$ & 9 & 10 & 10 & 2 & 1 & 1 & 5 & Online communities \\
\hline Caregiver 3 & No & No & $\begin{array}{l}\text { A few days a } \\
\text { week }\end{array}$ & 7 & 7 & 7 & 10 & 1 & 1 & 4 & I do not seek for help \\
\hline Caregiver 4 & No & No & $\begin{array}{l}\text { More than a } \\
\text { few times a day }\end{array}$ & 10 & 10 & 10 & 2 & 10 & 3 & 5 & I do not seek for help \\
\hline Caregiver 5 & Yes & $\begin{array}{l}\text { It differs } \\
\text { each year }\end{array}$ & $\begin{array}{l}\text { A few days a } \\
\text { week }\end{array}$ & 9 & 10 & 8 & 10 & 6 & 6 & 7 & $\begin{array}{l}\text { Friends Online } \\
\text { communities }\end{array}$ \\
\hline Caregiver 6 & Yes & No & $\begin{array}{l}\text { More than a } \\
\text { few times a day }\end{array}$ & 6 & 10 & 5 & 5 & 10 & 8 & 5 & $\begin{array}{l}\text { Friends Family } \\
\text { Specialized support } \\
\text { centers }\end{array}$ \\
\hline Caregiver 7 & No & No & $\begin{array}{l}\text { A few days a } \\
\text { week }\end{array}$ & 10 & 9 & 10 & 10 & 6 & 1 & 8 & I do not seek for help \\
\hline Caregiver 8 & No & No & I do not know & 5 & 10 & 10 & 5 & 3 & 1 & 3 & I do not seek for help \\
\hline Caregiver 9 & No & No & $\begin{array}{l}\text { More than a } \\
\text { few times a day }\end{array}$ & 10 & 10 & 10 & 5 & 10 & 8 & 5 & Online communities \\
\hline Caregiver 10 & Yes & Yes & $\begin{array}{l}\text { A few days a } \\
\text { week }\end{array}$ & 8 & 8 & 6 & 10 & 1 & 1 & 8 & $\begin{array}{l}\text { Family } \\
\text { Online communities }\end{array}$ \\
\hline Caregiver 11 & No & No & $\begin{array}{l}\text { Several times a } \\
\text { month }\end{array}$ & 4 & 10 & 10 & 5 & 1 & 1 & 5 & I do not seek for help \\
\hline Caregiver 12 & No & No & $\begin{array}{l}\text { More than a } \\
\text { few times a day }\end{array}$ & 8 & 10 & 6 & 4 & 1 & 1 & 2 & $\begin{array}{l}\text { Family } \\
\text { Online communities }\end{array}$ \\
\hline
\end{tabular}




\begin{tabular}{|c|c|c|c|c|c|c|c|c|c|c|c|}
\hline Caregiver 13 & No & No & $\begin{array}{l}\text { More than a } \\
\text { few times a day }\end{array}$ & 10 & 10 & 10 & 10 & 10 & 8 & 10 & Online communities \\
\hline Caregiver 14 & No & Yes & $\begin{array}{l}\text { More than a } \\
\text { few times a day }\end{array}$ & 8 & 7 & 8 & 7 & 1 & 1 & 3 & Family \\
\hline Caregiver 15 & No & No & $\begin{array}{l}\text { More than a } \\
\text { few times a day }\end{array}$ & 9 & 10 & 6 & 10 & 6 & 1 & 8 & $\begin{array}{l}\text { Family } \\
\text { In a polyclinic } \\
\text { Online communities }\end{array}$ \\
\hline Caregiver 16 & Yes & Yes & $\begin{array}{l}\text { Constantly } \\
\text { when I care for } \\
\text { a patient with } \\
\text { dementia }\end{array}$ & 5 & 4 & 1 & 2 & 10 & 7 & 2 & $\begin{array}{l}\text { Friends } \\
\text { Online communities }\end{array}$ \\
\hline Caregiver 17 & Yes & $\begin{array}{l}\text { I wouldn't } \\
\text { be able } \\
\text { without } \\
\text { my } \\
\text { husband } \\
\text { and my } \\
\text { son }\end{array}$ & $\begin{array}{l}\text { A few days a } \\
\text { week }\end{array}$ & 7 & 9 & 10 & 10 & 6 & 8 & 9 & $\begin{array}{l}\text { Family } \\
\text { Online communities }\end{array}$ \\
\hline Caregiver 18 & Yes & Yes & $\begin{array}{l}\text { A few days a } \\
\text { week }\end{array}$ & 5 & 10 & 5 & 9 & 8 & 8 & 1 & Family \\
\hline Caregiver 19 & No & No & $\begin{array}{l}\text { Several times a } \\
\text { month }\end{array}$ & 5 & 8 & 5 & 10 & 4 & 1 & 1 & I do not seek for help \\
\hline Caregiver 20 & No & No & $\begin{array}{l}\text { More than a } \\
\text { few times a day }\end{array}$ & 10 & 10 & 5 & 2 & 1 & 1 & 10 & Online communities \\
\hline Caregiver 21 & No & No & $\begin{array}{l}\text { More than a } \\
\text { few times a day }\end{array}$ & 10 & 10 & 7 & 10 & 10 & 9 & 9 & I do not seek for help \\
\hline Caregiver 22 & Yes & No & $\begin{array}{l}\text { More than a } \\
\text { few times a day }\end{array}$ & 10 & 8 & 9 & 1 & 10 & 10 & 6 & $\begin{array}{l}\text { Family } \\
\text { In a polyclinic }\end{array}$ \\
\hline Caregiver 23 & Yes & Yes & $\begin{array}{l}\text { More than a } \\
\text { few times a day }\end{array}$ & 8 & 10 & 10 & 1 & 2 & 3 & 6 & Online communities \\
\hline Caregiver 24 & Yes & $\begin{array}{l}\text { If I was } \\
\text { completely } \\
\text { involved in } \\
\text { caregiving, } \\
\text { there will } \\
\text { be no spare } \\
\text { time for } \\
\text { me and my } \\
\text { family }\end{array}$ & $\begin{array}{l}\text { More than a } \\
\text { few times a day }\end{array}$ & 7 & 9 & 8 & 10 & 8 & 5 & 6 & Family \\
\hline Caregiver 25 & No & No & $\begin{array}{l}\text { A few days a } \\
\text { week }\end{array}$ & 5 & 10 & 10 & 5 & 10 & 7 & 10 & I do not seek for help \\
\hline Caregiver 26 & Yes & No & $\begin{array}{l}\text { More than a } \\
\text { few times a day }\end{array}$ & 4 & 1 & 2 & 10 & 5 & 10 & 10 & $\begin{array}{l}\text { Friends } \\
\text { Family }\end{array}$ \\
\hline Caregiver 27 & No & No & $\begin{array}{l}\text { A few days a } \\
\text { week }\end{array}$ & 10 & 10 & 10 & 10 & 1 & 1 & 6 & I do not seek for help \\
\hline Caregiver 28 & No & No & $\begin{array}{l}\text { More than a } \\
\text { few times a day }\end{array}$ & 9 & 10 & 10 & 8 & 9 & 9 & 10 & Friends \\
\hline Caregiver 29 & Yes & No & $\begin{array}{l}\text { A few days a } \\
\text { week }\end{array}$ & 8 & 8 & 3 & 5 & 7 & 10 & 3 & Online communities \\
\hline Caregiver 30 & Yes & Yes & $\begin{array}{l}\text { I am not } \\
\text { stressed }\end{array}$ & 1 & 5 & 10 & 10 & 1 & 1 & 1 & I do not seek for help \\
\hline Caregiver 31 & Yes & Yes & $\begin{array}{l}\text { A few days a } \\
\text { week }\end{array}$ & 10 & 8 & 10 & 10 & 1 & 4 & 5 & $\begin{array}{l}\text { Friends Family } \\
\text { Online community }\end{array}$ \\
\hline
\end{tabular}




\begin{tabular}{|c|c|c|c|c|c|c|c|c|c|c|c|}
\hline Caregiver 32 & No & No & $\begin{array}{l}\text { A few days a } \\
\text { week }\end{array}$ & 8 & 8 & 9 & 8 & 10 & 6 & 7 & I do not seek for help \\
\hline Caregiver 33 & No & Yes & $\begin{array}{l}\text { A few days a } \\
\text { week }\end{array}$ & 10 & 7 & 9 & 6 & 9 & 9 & 9 & I do not seek for help \\
\hline Caregiver 34 & Yes & No & $\begin{array}{l}\text { Several times a } \\
\text { month }\end{array}$ & 7 & 9 & 4 & 9 & 2 & 4 & 8 & Online communities \\
\hline Caregiver 35 & No & No & $\begin{array}{l}\text { A few days a } \\
\text { week }\end{array}$ & 8 & 8 & 10 & 7 & 9 & 4 & 8 & Online communities \\
\hline Caregiver 36 & Yes & Yes & $\begin{array}{l}\text { A few days a } \\
\text { week }\end{array}$ & 7 & 10 & 8 & 3 & 10 & 1 & 9 & Online communities \\
\hline Caregiver 37 & No & No & $\begin{array}{l}\text { A few days a } \\
\text { week }\end{array}$ & 9 & 10 & 7 & 5 & 1 & 1 & 10 & Friends \\
\hline Caregiver 38 & No & No & $\begin{array}{l}\text { More than a } \\
\text { few times a day }\end{array}$ & 9 & 10 & 5 & 8 & 10 & 8 & 5 & $\begin{array}{l}\text { Family } \\
\text { Online communities }\end{array}$ \\
\hline Caregiver 39 & No & No & $\begin{array}{l}\text { A few days a } \\
\text { week }\end{array}$ & 9 & 9 & 7 & 1 & 5 & 7 & 2 & $\begin{array}{l}\text { Friends } \\
\text { In a polyclinic } \\
\text { Online communities }\end{array}$ \\
\hline Caregiver 40 & No & No & $\begin{array}{l}\text { Several times a } \\
\text { month }\end{array}$ & 4 & 7 & 3 & 1 & 1 & 1 & 5 & Online communities \\
\hline Caregiver 41 & No & No & $\begin{array}{l}\text { More than a } \\
\text { few times a day }\end{array}$ & 8 & 9 & 10 & 6 & 8 & 7 & 1 & $\begin{array}{l}\text { Friends } \\
\text { Family }\end{array}$ \\
\hline Caregiver 42 & No & No & $\begin{array}{l}\text { More than a } \\
\text { few times a day }\end{array}$ & 10 & 10 & 10 & 10 & 10 & 1 & 8 & Online communities \\
\hline Caregiver 43 & Yes & Yes & $\begin{array}{l}\text { More than a } \\
\text { few times a day }\end{array}$ & 6 & 8 & 8 & 8 & 6 & 2 & 2 & $\begin{array}{l}\text { Friends } \\
\text { Online communities }\end{array}$ \\
\hline Caregiver 44 & Yes & Yes & $\begin{array}{l}\text { More than a } \\
\text { few times a day }\end{array}$ & 10 & 10 & 10 & 1 & 1 & 1 & 10 & I do not seek for help \\
\hline Caregiver 45 & Yes & No & Constantly & 8 & 8 & 3 & 5 & 2 & 2 & 8 & Online communities \\
\hline Caregiver 46 & Yes & No & $\begin{array}{l}\text { A few days a } \\
\text { week }\end{array}$ & 8 & 8 & 10 & 5 & 5 & 7 & 2 & $\begin{array}{l}\text { In primary care } \\
\text { facility I received } \\
\text { unsatisfactory } \\
\text { treatment, thus, I did } \\
\text { not look for another } \\
\text { support source }\end{array}$ \\
\hline Caregiver 47 & No & No & $\begin{array}{l}\text { More than a } \\
\text { few times a day }\end{array}$ & 9 & 10 & 10 & 7 & 2 & 2 & 8 & $\begin{array}{l}\text { Friends } \\
\text { Family }\end{array}$ \\
\hline Caregiver 48 & No & No & $\begin{array}{l}\text { More than a } \\
\text { few times a day }\end{array}$ & 10 & 10 & 1 & 10 & 10 & 5 & 8 & $\begin{array}{l}\text { Friends } \\
\text { Online communities }\end{array}$ \\
\hline Caregiver 49 & No & No & $\begin{array}{l}\text { More than a } \\
\text { few times a day }\end{array}$ & 10 & 10 & 10 & 9 & 3 & 7 & 8 & Family \\
\hline Caregiver 50 & No & No & $\begin{array}{l}\text { More than a } \\
\text { few times a day }\end{array}$ & 8 & 9 & 5 & 3 & 2 & 1 & 5 & I do not seek for help \\
\hline Caregiver 51 & Yes & No & $\begin{array}{l}\text { A few days a } \\
\text { week }\end{array}$ & 8 & 8 & 8 & 10 & 6 & 1 & 10 & Friends \\
\hline Caregiver 52 & Yes & No & $\begin{array}{l}\text { A few days a } \\
\text { week }\end{array}$ & 8 & 8 & 3 & 9 & 1 & 1 & 2 & I do not seek for help \\
\hline
\end{tabular}

Copyright: (C2021 Venera Telzhan. This is an open-access article distributed under the terms of the Creative Commons Attribution License, which permits unrestricted use, distribution, and reproduction in anymedium, provided the original author and source are credited. 